\title{
Geoethics to Start Up a Pedagogical and Political Path towards Future Sustainable Societies
}

\author{
Silvia Peppoloni (D) and Giuseppe Di Capua *(D)
}

check for updates

Citation: Peppoloni, S.; Di Capua, G. Geoethics to Start Up a Pedagogical and Political Path towards Future Sustainable Societies. Sustainability 2021, 13, 10024. https://doi.org/ $10.3390 /$ su131810024

Academic Editor: Federico Martellozzo

Received: 29 July 2021

Accepted: 2 September 2021

Published: 7 September 2021

Publisher's Note: MDPI stays neutral with regard to jurisdictional claims in published maps and institutional affiliations.

Copyright: (c) 2021 by the authors. Licensee MDPI, Basel, Switzerland. This article is an open access article distributed under the terms and conditions of the Creative Commons Attribution (CC BY) license (https:// creativecommons.org/licenses/by/ $4.0 /)$.
Istituto Nazionale di Geofisica e Vulcanologia, International Association for Promoting Geoethics, 40128 Bologna, Italy; silvia.peppoloni@ingv.it

* Correspondence: giuseppe.dicapua@ingv.it

\begin{abstract}
The development of geoethics is at a turning point. After having strengthened its theoretical structure and launched new initiatives aimed at favouring the spread of geoethical thinking, geoethics must deal with some issues concerning the social organization of dominant cultures, the existing economic structures, and the political systems that govern the world. Nowadays geoethics must move towards the construction of a pedagogical proposal, which has a formative purpose, for future generations and the policy leaders, but also a political one, in the noble sense of the term, that is, concerning the action of citizens who take part in public life. The pedagogical and political project of geoethics will have to be founded on the principles of dignity, freedom, and responsibility on which to ground a set of values for global ethics in order to face planetary anthropogenic changes. Furthermore, this project must be inclusive, participatory, and proactive, without falling into simplistic criticism of the current interpretative and operational paradigms of the world, but always maintaining realism (therefore adherence to the reality of the observed facts) and a critical attitude towards the positive and negative aspects of any organizational socio-economic system of human communities. In our vision there can be no sustainability, adaptation, or transition in human systems that do not pass through an ethical regeneration of the human beings, who are aware of their inborn anthropocentric and anthropogenic perception/position and assume responsibility for the consequences of their actions impacting the Earth system. In fact, the ecological crisis is the effect of the crisis of humans who have moved away from their intimate human nature. Through this paper we want to enlarge disciplinary areas that should be investigated and discussed through the lens of geoethical thinking and propose geoethics for an ethical renewal of societies, making them more sustainable from a social, economic, and environmental perspectives.
\end{abstract}

Keywords: geoethics; sustainable societies; ecological humanism; ecological crisis; anthropocentric view; responsibility

\section{Introduction}

Geoethics [1,2], precisely because of its theoretical structure that is rooted in the geoscientific knowledge of the characteristics and dynamics of complex social-ecological systems [3-6], must question itself on the idea of a future human civilization, being nourished by ideals and carried out through a scientifically founded operational pragmatism. This implies that studies in the field of geoethics are enriched by and integrated with economic, sociological, legal, and human sciences reflections [7-16]. These reflections must not distort the essence of geoethics [2,16-18] but must complete its operational interface, so that from a long-term cultural project, geoethics can more rapidly transform into a pedagogical program and a political manifesto to also act and become effective in the short term.

We believe that this process of progressive enrichment of the perspectives of geoethics has to be based on two fundamental aspects:

(1) The unconditional recognition of human dignity: this step is essential for attributing dignity also to any non-human entity. In fact, if the human species is not capable of 
giving itself dignity with conviction, it cannot be able to recognize dignity in other entities. This recognition results into an articulated sense of responsibility of the human being towards him/herself and the other from him/herself, with the aim of creating the conditions for ecological humanism [16]. The recognition of dignity must also have centrality in pedagogical programs, since only a human being trained to give value regardless of personal utility or interest can initiate a political project of building a society capable of minimizing inequalities and achieving a respectful relationship with nature;

(2) The creation of an ethical reference framework for human action [16]; in their choices, humans must be supported by an ethical structure, a set of principles, and reference values that can guide their decisions and make them aware of the consequences of their interventions on natural processes and socio-ecological systems. Geoethics proposes principles and values capable of shaping the human perception of one's existential role in a gradually broader way, identifying and making explicit the ecological dimension of the human being, which does not deny the importance and value of humanity, whilst recognizing that its appearance and evolution on the Earth is linked to chance and contingency. Geoethics highlights the impossibility of postponing the construction of a culture in which the "Anthropos is assigned the unconditional responsibility of being part of a whole and an equal among all" [18].

When the anarchist French geographer Élisée Reclus (1830-1905) affirmed that "L'Homme est la nature prenant conscience d'elle meme" ("Man is nature that becomes aware of itself") [19], he seemed to already have grasped, more than a century ago, the responsibility that is now assigned to humanity: to taking care of the planet and of life in all its forms, as an act suited to one's own intimate human nature [16,20], as a precipitate of nature. Therefore, in this perspective, ethics is intended as a choice to be what you are by nature. Then, acting against nature is to act against oneself; it means giving shape to an existential dissociation whose failures are visible at all levels of human action including predatory economic systems, oppressive political systems, cultural systems based on power and domination without respect for plurality, de-humanized construction systems that uproot human communities from the ecological context, social systems deprived of territoriality and flattened on common cultural and spiritual forms and material needs, and technological systems that hide an aim of control or induction of needs behind the false perspective of providing means at the service of human progress.

The ethical renewal of the human being invoked by Edgar Morin [21] is the same as is advocated by geoethics [16,18]. In Peppoloni and Di Capua [18] a revision of the traditional concept of anthropocentrism is proposed, which frees it from more or less accusatory qualifications and from the contraposition with biocentric and ecocentric positions; the human being, starting from its natural anthropocentric perception, no longer arises as a final subject that in an utilitarian way satisfies its own needs through mechanisms of domination over what is non-human, but as a subject aware of being an integral part of the natural system and having to responsibly cultivate an attitude of care towards the planetary system. Therefore, a human open to listening and knowledge, who recognizes and perceives itself as a moral subject, and by virtue of this prerogative is naturally led to build its own vital space by establishing a relationship of respect with other living species and with the non-living elements that constitute the Earth system.

Geoethicality of a choice lies in being suitable to and in line with one's own naturalness, while its non-geoethicality is the effect of one's own existential dissociation, being against one's own naturalness, which also turns into a disease of the planet (habitat degradation, loss of biodiversity, soil impoverishment, ocean acidification, anthropogenic global warming, alteration of biogeochemical cycles) [22-24]. The "ecological crisis" is caused by a crisis of humans, primarily of those who have used political and economic power as an exercise of prevarication rather than of service. The current severe emergency can only be addressed by regenerating the human through a pedagogical action that considers the principles of dignity, freedom, and responsibility as the foundations of the educational 
and formative action of the new generations and of leaders, opening the space to a new political horizon. We argue that geoethics can become the bedrock on which to found new pedagogical and political trajectories, in order to face the ecological crisis.

In the following sections, firstly we highlight the fundamental characteristics, principles, and values of geoethics (Section 2); secondly, we make some philosophical and economic considerations from the perspective of geoethical thinking about the current ecological crisis (Section 3); thirdly, we analyse different positions regarding human-nature interactions in environmental ethics, and we discuss why, in our opinion, the ecological crisis is not due to an anthropocentric view (in its traditional meaning), but rather to a general process of de-responsibilisation of individuals favoured by bad policies or the prevaricating power of the lobbies (Section 4); finally, we propose geoethics as an ethics for society (Section 5). In Section 6, we conclude our paper by summing up the main results of our reasoning.

\section{The Structure of Geoethics: Fundamental Characteristics, Principles, and Values}

In this section of the paper, we focus on the structure of geoethics, as proposed in Peppoloni and Di Capua [16], describing its fundamental characteristics, the principles and values on which its theoretical framework is based, and the consequent actions that shape its practical application.

From this structure comes the geoethical vision already briefly described in Peppoloni and Di Capua [18], but which we will elaborate here, having two objectives:

(a) To highlight the meaning of geoethics for human life (thus definitively expanding geoethics to an extra-professional dimension);

(b) To provide more insights, aimed at suggesting further reflections on the cultural foundations of geoethics, framing its concepts and categories within human cultural history, and developing and applying geoethical thinking in the various fields of human knowledge.

The current structure of geoethics is the result of a process of cultural intra-professional development within geosciences started in 2010 [13]. The use of the word geoethics predates this year, but it is outside the scope of this paper to provide a history of geoethics and even less an exegesis of the meanings attributed to it.

In our analysis we refer to the definition of geoethics in [1]. The essential core of the definition asserts that geoethics "consists of research and reflection on the values which underpin appropriate behaviours and practices, wherever human activities interact with the Earth system [2] (p. 30), [25] (pp. 4-5), [26] (p. 5)" In Peppoloni and Di Capua it is noted that this definition "outlines the perimeter of the geoethical analyses, aims, and actions, underlining the need to first identify those values on which to shape a responsible and sustainable interaction with Nature" [18]. It can be specified that:

(1) Geoethical analysis consists of research and reflection. Geoethics is not prescriptive from an applicative point of view but is constantly looking for shared value references rooted in its founding principles. This makes it a living philosophy, capable of changing its implementation forms on the basis of the application context.

(2) The goal of geoethics is the identification of values that support appropriate behaviours and practices for interacting with the Earth system. Interacting is understood to be the relational form between human beings and the natural environment [16]. This relationship is subject to constant change, through action and feedback processes [2,16,27].

(3) By "appropriate behaviours and practices" we mean those that ensure a responsible and sustainable interaction between humans and the Earth system (building a house very close to a watercourse or a quiescent/active volcano is not an appropriate behaviour; mining activities that do not apply methods and technologies to reduce the environmental impacts and do not consider societal contexts of mining territories are not responsible practices). Such behaviours and practices must be consistent with 
those concerning the interactions between human beings themselves [16,20], in turn based on the unquestionable principles that are the basis of geoethics.

(4) The core meaning of geoethics encompasses the interaction between humans and the Earth system. However, there are several other disciplines which, although they do not strictly concern this specific context, deal with issues related to it, and therefore certainly can benefit from the results of geoethical analysis, and geoethics can also receive useful insights from them, to measure itself with disciplinary fields outside its defined theoretical and applied research field. After all, defining the field of interest of geoethics does not mean building a rigid dividing line between it and the other disciplines, but rather identifying a line of contact, a membrane along which a profitable osmotic exchange can take place. Moreover, reflecting on the relationship between the human and what is other than oneself (such as the natural system in which the human is immersed and of which it is an integral part) implies the construction of a sense of one's humanity. Additionally, this construction takes place within the set of speculative and emotional possibilities of human experience, including those offered by the relationship between the human and nature. After all, all the disciplines provide interpretations of the complexity of the world and nourish the creative richness of humankind, contributing to the construction of the idea that people have of themselves, as well as of the relational mechanisms, both inter-species and extra-species. It is evident that disciplines such as economics (study of economic systems, supply chains of raw materials and goods, production mechanisms, and distribution of profits and incomes), politics (organization of legislative and decision-making bodies and mechanisms of civil participation in public life, definition of decision-making chains, roles and responsibilities of social actors), sociology (analysis of social characteristics, rules and processes, organization of the structures of society, of the mechanisms of knowledge production and their influences on human communities, of the relationships between social phenomena and other events), art (search for forms of expression and creation of products of human sensitivity and manual skills obtained through a set of rules, experiences, and techniques), as well as geosciences (study of forms, dynamics, and physical, chemical, and biological processes that govern the Earth system), engineering (development of techniques and processes of intervention and transformation on matter in order to create artefacts and technological tools, theoreti$\mathrm{cal}$ and/or application processes for the creation and/or management of anthropic processes), geography (analysis of physical, biological, and human phenomena that affect the earth's surface and that, in their interaction, modify its appearance), architecture (modelling of living spaces, urban and natural), psychology (investigation of psychic, conscious, and unconscious, cognitive and dynamic processes), or medicine (study of diseases and therapies, health services and monitoring), whether directly or indirectly affecting the relationship between the people and the Earth system, as they change the way in which that dynamic relationship, made up of actions and feedbacks, is structured.

\subsection{The Fundamental Characteristics of Geoethics}

Geoethics is centred on the human agent $[2,16]$. This characteristic must be understood as referring to the single individual as a quantum of the social system. Indeed, it would be correct to include in the definition of human agent also any human group, which acts as a single corpus. Instead, geoethics focuses precisely on the individual as the agent of change. It is the cooperation of individuals on a common basis of principles, values, and intents, and not their social structuring dictated by predefined rules of belonging to a human group, which must be considered as the way to implement geoethical thinking. In geoethics, the individual is placed at the centre of the geoethical context to give strength also to the action of the group, considered a communion of individuals consciously adhering to shared principles and values and having common goals and visions, single persons who, by free 
choice, act cooperatively in accordance with their human nature, their needs, aspirations, and decisions.

Geoethics is characterized as an ethics of virtue referred to the human agent $[1,2,16]$, based on the principles of dignity, freedom, and responsibility $[16,18]$ that are discussed in the next paragraph. To adhere to an ethics of virtue, it is not enough to adapt one's behaviour to a system of values, but it is necessary to embody those values until they become innate to one's essence. In other words, to act ethically you have to be a certain type of person, and not just behave in a certain way.

Adherence to the shared principles and values of geoethics is a free decision that shapes all the interaction dimensions of human experience, identified as domains of geoethics, namely individual, interpersonal and professional, social and environmental domains [2,17]. These domains or levels of interaction that are consecutively broader and more complex are the spheres within which the responsibilities of the individual are declined $[2,16,20]$.

The geoethical virtue is implemented through a process of seeking awareness and sharing, aimed at resolving issues, taking into account the value of geoscientific knowledge. Geoethics focuses on individual responsible action, based on the adoption of ethical and social reference values. Its development and application take place within a pragmatic process of reviewing choices, which are open and continuous.

Behaviours inspired by geoethics are based on scientifically-based choices [2]. Qualified geoscientists, with their valuable know-how on terrestrial, oceanographic, and planetary dynamics, and aware of their social role, are able to suggest choices, behaviours, practices, and functional ways of interacting with the Earth system, and also above all to those who are not experts in geosciences, such as policy makers, legislators, or ordinary citizens.

Choices in line with the geoethical vision cannot be affected by radicalism but must take into account the variety of cultures and social conditions that characterize the interrelated human mosaic present on the planet, just as they cannot ignore the physicalchemical-biological and geological peculiarities of the territories subject to anthropogenic interventions. These choices must therefore be spatially and temporally contextualized [2]. Any analytical and critical approach to environmental problems cannot ignore the local human communities, if it wants to guarantee to the various groups, and by extension to future generations, the same opportunities for social, economic, and cultural development, in a natural environment not degraded in any sense $[16,20]$.

It is clear that any choice or solution in the area that does not take into account local realities risks being perceived as an imposition and can provoke adverse reactions, even violent ones, by the population, which may have different points of view, beliefs, needs, objectives, and expectations $[16,20,28]$. This is the condition that often occurs when decisions by authorities are not the result of an inclusive and participatory process with citizens, in particular if they concern works of great socio-environmental impact such as infrastructural networks, underground drilling, the construction of artificial reservoirs, landfills, or deposits of nuclear waste. Similarly, choices that do not consider the possible progressivity over time of the impacts on the environment may appear to be effective solutions in the short term, but lead to further problems over longer periods, or vice versa.

The contextualization of practices and interventions is a fundamental characteristic of geoethics, which in Peppoloni et al. is called as a relativism of geoethics [2] and in Bohle and Marone as a pluralism of geoethics [14]. This feature ensures a variety of approaches and modes of action within a shared framework of geoethical values. After all, the definition of prescriptive behaviours and rules that underestimate the importance of the context in which they must be applied could have the effect of inducing antagonistic tensions and an "a priori" rejection by the people affected by a given problem [16]. The geoethical approach takes into account the space-time complexity of existing physical and social realities, identifying the technical, environmental, economic, cultural, and political limits 
of human action, with the awareness that similar problems may require different solutions, geoethically correct, in different contexts [2].

\subsection{The Principles of Geoethics}

It is necessary to reflect that geoethics is a human construction and as such has value in relation to the biological, anthropological, and cultural mechanisms that characterize the peculiarities of our living species. It is not possible to attribute to geoethics an operational value for non-human entities, but these entities can be subject to geoethical analysis albeit from an inevitably anthropic perspective.

The structure of geoethics is based on three fundamental, unquestionable principlesdignity, freedom, and responsibility [16].

Dignity is expressed and implemented by recognizing a value, and in attributing value to the agent and to what is considered the object of his/her actions. Freedom is the fundamental requirement, the necessary condition for being able to choose and therefore act ethically. Responsibility is the ethical criterion that guides the action of the human agent, who unconditionally accepts his/her systemic role within the Earth system and takes into account the possible consequences, even negative ones, of his/her actions.

Humans are complex beings and as such have the responsibility to act in accordance with their complex biological, emotional, and rational natures. Acting in conformity implies knowing oneself, it means being aware of one's own possibilities and limits, it means recognizing oneself as a moral being and therefore able to pose ethical problems and make ethical choices, and starting from this awareness to try to understand the world and to act according to one's own abilities and possibilities.

Geoethics provides an ethical framework of principles and values on which to build the relations of the human unity of action in the various relational domains, or domains of geoethics. Integrity guides consistent behaviours within each of these four domains of human relations. Additionally, this enriches human existence with meaning, because it makes human beings more functional to themselves and to what is other than themselves; in this perspective, the human beings assume a duty towards themselves, towards others and progressively towards wider spheres of interaction, up to include the entire Earth system. It is in this way that geoethics invites each individual to become part of the whole, through the indissoluble uniqueness of every human being. The feeling of being at the centre of oneself is not selfishness, but it is the fullness of one's authenticity as humans; it is a species identity, since recognizing one's own value allows in turn one to give value to what is other than oneself.

Thus, the individual acts in the four domains of geoethics, following an analytical and prudent approach based on the principle of responsibility.

The fundamental principles on which the building of the values of geoethics is based are flanked by three aspirational principles: awareness, justice, and respect. Their implementation is the aim of the geoethical action that creates geoethical socio-ecological systems.

A description of those six principles (three fundamental and three aspirational) is given in Table 1. 
Table 1. The principles of geoethics.

\begin{tabular}{|c|c|c|}
\hline \multicolumn{2}{|c|}{ Principles } & Description \\
\hline \multirow{3}{*}{ Fundamental } & Dignity & $\begin{array}{l}\text { Recognition of the existential rights and values to anyone } \\
\text { (including oneself) or to anything. Dignity presupposes } \\
\text { the intention to respect oneself and others. Geoethical } \\
\text { action is functional to recognize the right to existence for } \\
\text { any entity and its value. }\end{array}$ \\
\hline & Freedom & $\begin{array}{l}\text { Existential condition of the human agent, thanks to which } \\
\text { the individual is able to think, process, and choose } \\
\text { without external constraints that limit his/her intellectual } \\
\text { and operational faculties. }\end{array}$ \\
\hline & Responsibility & $\begin{array}{l}\text { Ethical criterion of free human action. Responsibility } \\
\text { implies making a commitment to make a free decision } \\
\text { that can have both negative and positive consequences. } \\
\text { Responsibility involves an intra-personal relationship and } \\
\text { an extra-personal relationship with other parties who act } \\
\text { or with the subject of the action. }\end{array}$ \\
\hline \multirow{3}{*}{ Aspirational } & Awareness & $\begin{array}{l}\text { Human prerogative of being conscious of one's systemic } \\
\text { role within the natural architecture, and of the limits that } \\
\text { govern the human operating space within the } \\
\text { Earth system. }\end{array}$ \\
\hline & Justice & $\begin{array}{l}\text { It is the full recognition of rights. It is reflected in the } \\
\text { rightness of human relationships in space and time and is } \\
\text { able to ensure the right to intra-generational and } \\
\text { inter-generational self-determination. }\end{array}$ \\
\hline & Respect & $\begin{array}{l}\text { It is the concrete and conscious implementation of the } \\
\text { fundamental principle of dignity, guaranteeing full } \\
\text { expression of the existential potential of each biotic and } \\
\text { abiotic entity. }\end{array}$ \\
\hline
\end{tabular}

\subsection{The Values of Geoethics}

In Peppoloni and Di Capua, a set of values for geoethics were proposed [29], which were then incorporated into the Cape Town Statement on Geoethics [30]. Among them, in addition to professional ethical values, some important concepts of geosciences are described, such as geodiversity, geoheritage, and geo-conservation, which are strictly linked to principles of dignity and respect referred to in Table 1. Geodiversity, geoheritage, and geo-conservation are concepts that have cultural relevance [31,32], since they shape the meaning humans give to their relationship with the abiotic environment [29]. For this reason, those concepts can be considered cultural values for geoethics, visible and tangible expressions of natural reality, capable of sense-making and producing emotions in humans. In [29], other concepts such as sustainability, prevention, and geo-education are proposed as social values of geoethics, essential for guiding societies and designing societal policies and strategies to face global anthropogenic changes. Values described in [29] are deepened in [2]. In Peppoloni and Di Capua [16] the scheme of geoethical values is further developed and organized according to the four domains of geoethics. In the field of geoethics, virtuous actions respond to the principle of responsibility [33], the ethical criterion of action [34]. In geoethics, personal, social, group, and religious morals converge, finding points of contact in the set of geoethical values proposed in Table 2. Therefore, geoethics does not deconstruct the various moral systems that guide human choices, but it tries to propose a synthesis that can be acceptable for the various socio-cultural contexts that characterize human diversity. 
Table 2. The values of geoethics (from [16]).

\begin{tabular}{|c|c|c|c|c|}
\hline Geoethical Domain & & Features & & Values \\
\hline Self & Responsibility & rooted into individu & thics & \multirow{4}{*}{$\begin{array}{l}\text { Honesty, integrity, accuracy, } \\
\text { reliability, transparency, } \\
\text { listening, sharing }\end{array}$} \\
\hline \multirow{3}{*}{ Inter-personal } & \multicolumn{3}{|c|}{ Responsibility-informed social relations } & \\
\hline & \multirow{2}{*}{$\begin{array}{l}\text { Responsibility-informed } \\
\text { professional relations } \\
\text { (deontology) }\end{array}$} & Professional ethics & \multirow{2}{*}{ Codes of ethics } & \\
\hline & & Research integrity & & \\
\hline Societal & \multicolumn{3}{|c|}{ Responsibility towards social stakeholders } & $\begin{array}{l}\text { Equity, inclusivity, cooperation, } \\
\text { adaptation, prevention, } \\
\text { sustainability, geo-education, } \\
\text { inter- and multidisciplinarity }\end{array}$ \\
\hline Environmental & \multicolumn{3}{|c|}{ Responsibility towards the Earth system } & $\begin{array}{l}\text { Stewardship, sustainability, } \\
\text { impact minimization, protection, } \\
\text { conservation, enhancement }\end{array}$ \\
\hline
\end{tabular}

In a schematic way, geoethics is structured in fundamental principles, from which descend a set of values that guide action towards the implementation of aspirational principles (Figure 1).

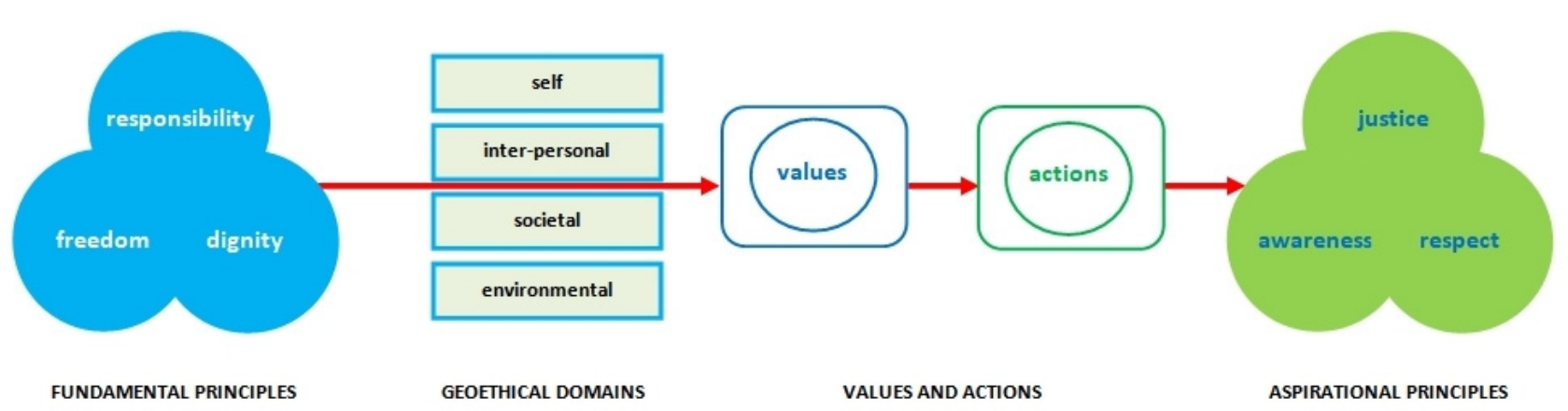

Figure 1. Poietic process of geoethics.

Following the values of geoethics means putting into practice a series of actions that have a different connotation depending on the geoethical domain considered.

Therefore, when responsibility is applied in the individual and inter-personal domains, virtuous geoethical agency produces actions that bring individuals closer to their inner dimension, making them more aware of their responsibilities towards the human groups to which they belong, in the same way that the agency also contributes to carrying out those actions that are right (which recognize rights) in relation to the extended dimension of society, since they concern the intra-generational and inter-generational spheres.

When responsibility is applied to the social domain, the actions of individuals are guided by the values of equity, inclusiveness, cooperation, adaptation, prevention, geoeducation, and inter- and multidisciplinarity and are aimed at creating a fairer society for present generations, and to build solid foundations for a fairer society for future generations as well.

Finally, when responsibility guides actions in the environmental domain, the values of stewardship, sustainability, minimization of anthropogenic impacts, and protection and conservation of ecosystems are implemented. The implementation of those values in turn produces well-being and happiness also for the human being. The result is actions that respect the environment, which promote and/or implement initiatives for the development of environmental-friendly and low-energy anthropic processes, low carbon and renewable energies, reduced-depletability management of georesources, and a low waste and circular economy [16]. These actions, which are respectful of geo-biodiversity and social-ecological systems, are expression of the principle of respect for all the biotic and abiotic entities of the 
Earth system regardless of their possible instrumental and functional value for the human being.

The structure of geoethics is the bedrock on which to contribute to building a new trajectory, narrative, and vision of the world. It is global ethics for a human globalized community of destiny.

\section{Ecological Crisis as a Crisis of the Human Being: Philosophical and Economic Considerations from a Geoethical Perspective}

We argue that to give value to nature that is not of exploitation or mere functionality for the human being, we have to become capable of giving greater value to the human being, especially in times of growing planetary inequalities, with prevarications against minorities and local indigenous communities [35-37], accentuated by economic globalization processes [38-40]. It is no coincidence that when we talk about the ecological crisis, we must also take into account social issues, such as inequalities, poverty, solidarity, rights, exploitation, or integration. The ecological crisis is also the direct effect of the crisis of the social, economic, and political organization systems [41]. Ultimately, it is a crisis that invests the human being in all the experiential and existential spheres. This is the focal point from which to start to develop a pedagogical project aimed at proposing geoethics to society as a whole for shaping future citizens of the world, which creates a policy inspired by the principles and values of geoethics, which contrasts with the selfish interests of limited power groups and is fully at the service of humanity.

In this vision, the human must be placed at the centre of the general interest of society, supported by an ethical reference framework that guides his/her decisions and increases awareness of his/her responsibilities in building the technological and economic future of societies, with the help of legal frameworks that implement a renewed vision of politics.

In the late 1970s, the German philosopher Hans Jonas (1903-1993) was very concerned about an evolving technology that lacked clarity and awareness of the problems that could arise from its application. Jonas invoked the principle of responsibility as an ethical criterion for human action, also in the perspective of respect for future generations who will inherit the Earth as a dwelling place [33]. According to Jonas, the responsibility is fed by fear, even by the fear of extinction. We consider that it is not fear that can make the human being more responsible, but the awareness of one's own value and limitations, which can only arise from in-depth knowledge of the issues, the fair comparison of ideas, and the training to a culture of the scientific method.

Often the lack of knowledge of problems and possible solutions, and the scarce awareness of their technical, social, cultural, ethical, and economic implications causes citizens to delegate decisions of crucial importance for themselves and the communities to which they belong to small political and economic elites. However, it is the knowledge of problems that increases awareness, which therefore becomes the objective of both individual and social self-determination, as an essential step to give birth to a humanity that is responsible for taking care of itself and the planet.

It is evident that a pedagogical and political project based on geoethics, as any other project focused on a renewal of the ethical dimension of humans, inevitably collides with strong resistance by interest groups, autocracies, theocracies, and oligarchies. Certainly it should be a factor for the policy makers who are above all trained to achieve those ambitious general objectives and who are consequently capable of implementing authentic and functional leaderships that guide humanity towards common and beneficial objectives.

There seem to be no alternatives - in this historical moment, it is necessary to make a real leap in our evolutionary path, that must be achieved in a few decades, and whose importance and scope could be greater than any other passage Homo sapiens has experienced in the past. Basing politics on the principles of dignity, freedom, and responsibility means delving into the heart of the issues that afflict humanity, giving an operational perspective to the numerous criticisms of the capitalist system [42-46], held by many as the responsible driver for the current global crisis. Renewing the ethical dimension of humans also means radically changing the forms in which they organize their production systems and 
communities, accommodating technical and linguistic obstacles that do nothing but create other clashes or the raising of ideological enclosures.

For centuries, the capitalist economic system, although changed in its forms and articulations due to progressive cultural, social, and political changes, has monopolized the modes of production and relationships among individuals and between them and nature, by producing on the one hand an enormous improvement in the quality of human life and wellness, even if only for a part of the world, and on the other hand by powerfully increasing the anthropic pressure on social-ecological systems $[47,48]$. This has led to a progressive deterioration of the human habitable space and a strong reduction in biodiversity [22,23,49-53], which now requires from humanity new trajectories of thought and action $[16,18,20,45,51-57]$. The essentially instrumental vision of nature, which is considered linked to capitalism [46], does not fit into the vision of geoethics. For the principle of dignity, geoethics recognizes a value in itself also to natural entities. Similarly, the figure of an aware and responsible individual as defined by geoethics prefigures new forms of active consumer citizens, who can make the difference with their purchasing choices. This could drive towards an economic paradigm shifting. An economy that does not take into account the value of the human and the natural environment stimulates constantly the creation of induced needs and false expectations for passive consumers, forcing the individual to artificial lifestyles based on the compulsive purchase of goods, even unnecessary ones. The ultimate effect is the increase in the ecological footprint of the economy, the rapid reduction of non-renewable natural resources, the homologation of needs, the repression of individual specificities, and the creation of social tensions between those who can possess and those who can only aspire to possession.

It is also evident that a critical analysis of any kind of system that has existed for hundreds of years cannot be addressed in the short space of an article, given the complexity of its historical evolution, of its benefits and negative effects, as well as of its pervasiveness in different human civilizations.

Human societies are very complex, globalized, and integrated. The change, however radical it may be, will have to be managed with prudence and foresight, at risk of further failures, and "-radicalness in purpose should not be conflated with a call for instant revolution, tearing down the system or hostility to dissenting ideas. Radicalness in purpose is equivalent to holding a vision or belief in what could be possible if $\mathrm{X}, \mathrm{Y}$, or $\mathrm{Z}$ was to change, an imaginary that stirs up energy, commitment, and persistence in taking the many incremental steps required to get there. Sociologists use the term 'imaginary' to capture more than ideas: it includes a set of values, institutions, laws, and symbols with which people imagine their social whole. Without this combination of radical imaginary and persistent progress toward it, not much transformation will happen" [58]. This means that great care must be taken not to place oneself outside a historical-cultural perspective and not to deconstruct a cumulated culture to the point of dangerously destabilizing it. As Edgar Morin points out, human history is not free from grim regressions [21].

Mazzucato proposes that "we fundamentally restructure capitalism to make it inclusive, sustainable, and driven by innovation that tackles concrete problems. That means changing government tools and culture, creating new markers of corporate governance, and ensuring that corporations, society, and the government coalesce to share a common goal. [59]" For Löwy there is the need to embrace ecosocialism as a radical alternative to the capitalist system [60].

In our vision, profound economic, political, social, and cultural changes are possible only through an authentic regeneration of the human being on an ethical level [18], as proposed by Morin [21]. Therefore, we believe that the project of geoethics, which is to put the individual at the centre of human interest, his/her dignity, freedom, talent, and creativity, is an essential condition to make humanity responsible, to start changing current economic paradigms and create new forms of economic production and work organization, shaping them through the principle of intra-generational and inter-generational responsibility and the principle of dignity, aimed at recognizing human rights and guaranteeing environ- 
mental protection. This is the vision on which our proposal for a Charter for Responsible Human Development is founded [16], which lists nine universal human duties that should complement the universal rights already promulgated by the United Nations [61].

\section{In What Terms Is the Vision of Geoethics Anthropocentric?}

Placing the human at the centre of the geoethical vision of the world inevitably recalls the concept of anthropocentrism [62]. It should be clarified that, as already stated by Peppoloni and Di Capua [18,63] and Peppoloni et al. [2], anthropocentrism in geoethics is criticized in its traditional meaning but is reformulated in light of the principle of responsibility, as an ethical criterion for the agency.

The anthropocentrism referred to indicating positions of prevarication of human interest on the right to existence of any other living and non-living entity, is a concept completely rejected by geoethics. It is contrary for geoethics to attribute to nature only an instrumental/functional value for our species, or to think that nature can be managed according to a relationship of subordination with respect to the needs of humanity. In the anthropocentric vision stricto sensu, nature has neither status nor value in herself. Consequently, the use of the planet's natural resources is functional to ensure satisfactory standards of living for the human being, whose rights are placed before those of any other living entity. Usually, the development of the current economic, political, social, and cultural paradigms that have led to the over-exploitation of natural resources and the great inequalities between the rich and the poor people of the planet is traced back to anthropocentrism. Anthropocentrism would therefore underlie predatory capitalism and in some way would support the most selfish part of the human being, almost justifying it, and leading him to perform even petty acts towards his fellows and towards what is other than itself. This negative vision would leave no other possibility than to embrace different positions, such as those conceived by biocentrism, ecocentrism, or geocentrism.

In biocentrism $[64,65]$ nature possesses a value in itself, regardless of the human being, who is considered a living being of equal importance compared to the other ones that populate the Earth and who is required to safeguard and conserve nature also to protect itself, in the need to find a balance that guarantees its survival within the richness of biodiversity. Ecocentrism [66-69] also goes beyond the biocentric position, attributing an intrinsic value to nature intended as the totality of what constitutes it, as a system of relationships. Humans, and in general all living beings, are considered an integral and inseparable part of everything else, and the value of nature taken as a whole is considered superior to the value of each organism considered individually. In this way, ecocentrism moves the human being from a position of centrality with respect to nature, which determines our sense of domination over nature itself, and lead him/her back to a position of a peer among other peers. Additionally, in the most extreme positions, ecocentrism also leads to considering the human being as an element that can be sacrificed if necessary, for the benefit of the preservation of nature as a whole. The biocentric and ecocentric positions would guarantee by humanity attitudes and therefore actions respectful of Nature, recognizing its full existential dignity [70]. Especially in the case of ecocentrism, this point of view seems completely incompatible with the current economic systems and global social organization. Finally, the geocentric position can be understood as a further systemic extension of the ecocentric positions. The Earth has an objective, self-produced systemic value, which does not therefore depend on those species that can recognize or attribute that value to it, a value that the Earth has by virtue of its relationships, value that is higher than the value of single species and single ecosystems that constitute it, as each part of the planetary system has reason to exist as part of the relationships constituting the whole [70].

Anthropocentrism, biocentrism, and ecocentrism (with its geocentric extension) are positions of environmental ethics [71], which have been given very complex meanings. Furthermore, some adjustments and further specifications in the definitions have been made over time: for example, a strong anthropocentrism has been defined as opposed 
to a weak one [72]. These specifications appear as attempts to overcome the rigidities of the different positions, which do not really fit separately the human complexity and the complexity of the relationship between human beings and nature. In any case, our conviction remains that all these positions descend from an inevitable anthropocentrism of species, in other words from a perception of things that for us, as humans, can only be anthropocentric, namely referred to the position that human beings give to themselves in relation to the other than themselves. As human beings, we cannot fail to have an anthropocentric vision [73]. Furthermore, biocentric and ecocentric positions are anthropocentric concepts, since they are developed and expressed by the human being. They are symbolic representations of our perception of a world of relationships to which we assign an ethical meaning.

Conceiving anthropocentrism in these terms, i.e., referring to the inevitable perception that the human species has of its position on Earth, is not in contradiction with being respectful of nature [74] and acting responsibly towards it, having understood that we are an integral part of it and that by protecting nature we safeguard also ourselves.

Unfortunately, anthropocentrism, biocentrism, and ecocentrism have become terms in strong contraposition. In the case of biocentrism and ecocentrism, for example, the specificity of every living species, including the human species, is not considered as a given reality, but there is the tendency to amalgamate the peculiarities of each individual in a single apparently holistic dimension, without realizing that this operation is intrinsically anthropocentric.

Moreover, there is another important aspect to be considered, that these positions can also induce a deep sense of guilt in the human being, regardless of the responsibilities of the present and the opinionated attitude of looking at past history with the sensitivity and moral frameworks of the current time. The sense of guilt does not allow clarity of action, but risks acting as a superstructure; that without being realised, it directs our choices, thus questioning the possibility of acting ethically, scientifically, and with common sense. The final result is that the sense of guilt feeds that feeling, strongly anthropocentric, which leads us to perceive ourselves as the rescuer of the environment, the planet, the cosmos. This highlights once again the persistent dichotomy between humans and nature, which is dominant all in Western cultures, that ontological fracture that comes from afar [75] (pp. 20-21), [76] and that we try to hide from it by using the words of elusive definitions.

We think a new attitude is needed. Environmental ethics has explored possible ways of relating to Nature and synthesized them in positions that have entered into conflict with each other [62,74], sparking endless discussions that have in fact created obstacles on the operational level, that we have to remove quickly if we want to give common answers to global problems.

Geoethics seeks to go beyond the contrapositions and make a synthesis, incorporating the concepts of anthropocentrism, biocentrism, and ecocentrism in a unitary vision, which saves the best intuitions of the categories of environmental ethics and uses them to develop new paths, more linked to reality, more effective on a practical level. To do this we recall some points of utmost importance in this synthesis process:

- Human beings have been changing their ecological niche for at least 12,000 years [77]. It no longer makes sense to speak of a "de-humanized" nature. We are nature, an integral part of natural reality and dynamics. We legitimately seek to create and protect our living space in the evolutionary and competitive game of nature herself. Our humanity, however, also opens up other dimensions to us, precisely those of reason and the possibility of choosing. We are moral subjects. We can therefore make ethical decisions, to live more responsibly in the future.

- Nature does not need us to regenerate, change, and evolve. We are not central to natural architecture, as the deep time of geology demonstrates, but we can legitimately build our living space, like other living species. Our species can recognize and ensure dignity also to what belongs to other species and to what is non-living. Additionally, this gives us a lot of responsibility towards everything that is other than us. 
- It is necessary to distinguish between the perception that humans can have of themselves with respect to everything that is other than them and their concrete actions, being in relation to what is external to them. Geoethics admits that it is not possible for humankind to leave the anthropocentric point of view, intended as referred to the perceived position on the Earth. The biocentric and ecocentric visions themselves are not exempt from an anthropocentric perspective, since they were thought and argued by people. However, in implementation, it must be acknowledged that humans try to change reality on the basis of their needs and expectations. However, it is necessary to be aware that primary needs and human expectations (sometimes secondary or induced needs) do not coincide, otherwise the predatory aspect of our human nature (which in any case exists and feeds on expectations) can prevail over the part of us that seeks after respect for and harmony with nature, that part that can instead find balance with the satisfaction of basic human needs.

- We should honestly ask ourselves if we want to change fundamentally our overall way of life, including our relationship with nature, progressively transforming ourselves from ruthless predators without the capacity for foresight, into conscious moral subjects, able to grasp the need for sustainability, capable to cultivate and implement that dimension of care and sharing which is one of the best evolutionary qualities achieved by our species. We can choose whether or not to do it.

- The identification of an ethical criterion for human action on the planet is crucial. For geoethics, this criterion is the principle of responsibility.

For all these reasons, geoethics accepts the different visions of environmental ethics, believing that each of them contains important elements of truth. Geoethics does not deny the anthropocentric vision, by meaning this as connected with the modality of the human self-perception, and declines it in light of the principle of responsibility, assigning to the human being the responsibility to act by attributing to nature an intrinsic value. In these terms, geoethics incorporates the vision of biocentrism, which is capable of grasping the value of natural life in itself, considering this conception fundamental to recognize the value of nature that resides also in us humans, and through respect for ourselves, to strengthen respect for nature in a virtuous circle that is self-sustaining. Finally, geoethics embraces the key concept of the ecocentric vision, which is the systemic dimension and that also belongs to geoscientific knowledge, a dimension linked to the relationships that are established between the constituent elements of nature and that allow one to grasp the meaning of the whole and the link between the parts. Geoethical thinking emphasizes that we live in a system of relationships, of which we are an integral part, and which we must take into account in our actions. The value of the single element is part of the value of the whole.

Geoethics grasps the profound meaning of anthropocentric, biocentric, and ecocentric positions and synthesizes them in a vision that can be defined as "ecological humanism" $[16,18,20]$. Ecological humanism rejects the traditional anthropocentric conception of a human being dominating nature, to open the vision to what Dubos defined as an "enlightened anthropocentrism" [78].

The vision of geoethics is centred on human agents who become aware of the partiality and relativity of their rational, sensitive, and emotional experiences. Geoethics assigns to the human being, part of a whole and equal among all, a centrality in the Earth system in terms of responsibility and not of exercise of domination and power. In this sense, geoethics acknowledges and goes beyond the categories of environmental ethics, which would otherwise remain in conflict with each other and hinder the achievement of a common vision, above all by preventing a rapid operational human response to the urgent global environmental, social, and economic challenges, and the adoption of policies respectful of humanity and nature at the same time.

Ultimately, we do not believe that perceiving oneself as anthropocentric, that is, positioned at the centre of reality with reference to the human perceptive and experiential status, is the cause of the desire for domination and exploitation over nature. 
The predatory and prevaricating attitude, which is an underlying cause of today's ecological crisis, refers to the concept of anthropocentrism in its most negative and traditional meaning, which conceives nature, the Earth resources, the environmental heritage, as exclusive prerogatives of the human being, without considering the consequences that an irresponsible exploitation can bring to social-ecological systems.

In our view, the real cause of the exercise of that dominion is due to a scarce, if not completely absent, assumption of social and environmental responsibility of individuals, driven by political and economic power groups that govern authoritarian societies, or promote their own partisan interests within democratic processes without considering the common good. Those groups are not inclusive and tend to deprive ordinary people of the responsibility to act for their own good, for the good of society and the environment, in such a way as to preserve their prerogatives of exercising power. The mechanism of de-responsibilisation is implemented through the induction (control) of induced needs, the shifting of attention to secondary issues, and the construction of an idea of a paternalistic state $[79,80]$. The induced social effect is to feed an egoistic dimension of needs and to induce feelings of apathy and passivity in the citizens towards general decisions. It is therefore not the anthropocentric human perception that produces the mechanism of exploitation and deterioration of the environment, but rather the general process of deresponsibilisation of individuals implemented by bad policies or by the exercise of a prevaricating power of the lobbies.

The implementation of inclusive decision-making mechanisms, of educational processes aimed at increasing the social and environmental awareness of citizens, and the sharing of responsibility of all components of society could initiate a process of regeneration of the commitment of individuals towards the community and the environment.

\section{Geoethics for Society}

The structure of geoethics has not only the value of intellectual speculation on the forms in which geoethical thinking is articulated and on the lines along which its applicative potential can unfold. It is the basis of a pedagogical and political project to renew human beings so that they can take on the responsibility of building the future on new ethical assumptions, aspiring to a more aware, just, and respectful world.

Geoethics is a philosophy of complexity, an ethics of responsibility, and a practice of civil and environmental commitment of aware citizens.

In geoethics we have tried to link instances, categories, principles, and values that are already present in culture and practice, giving life to a theoretical framework that incorporates many elements, reflections, and considerations that animate philosophical and political discussions, which is developed starting from philosophical, sociological, economic, and scientific reflections. We think that a robust vision is missing that is able to address environmental issues, which are also economic, social, cultural, and scientific issues-a vision that knows how to combine causes and effects, that knows how to look at issues of global relevance in a critical and rational way, but always from scientific and philosophical perspectives.

Geoethics is:

- Wide (its interests are focused on different topics);

- Multidisciplinary (it has a cooperative, integrated, if possible holistic approach to problems, also through the overcoming of sectoral languages to reach the intersection and integration of knowledge);

- $\quad$ Synthetic (expresses a position of synthesis between different existential concepts and the relationship between the human being and nature, which can be defined as ecological humanism);

- Global and local (its issues of interest have both a local dimension of intervention and a global one that can be extended to the entirety of the Earth system); 
- Pedagogical (the structure of geoethics is a model of cultivating one's own ethical dimension, to achieve greater awareness of the value of human identity, not in terms of exercisable power, but of respect for the dignity of what exists);

- Political (geoethics criticizes the materialism, selfishness, and consumerism of capitalism, prefiguring a profound cultural change of economic paradigms, and advocates the right to knowledge as the foundation of society).

These characteristics, which must be considered as additional to those illustrated in Section 2.1, also define more fully the educational and political objectives of geoethics for society.

States should strive to constructively implement the principles of dignity, freedom, and responsibility that are the basis of geoethics, inserting them within their constitutional charters, where they are not already explicitly referred to, so as to create the conditions for the development of legal reference frameworks, able to ensure (a) the conservation of ecosystems, and (b) the implementation of the fundamental right to knowledge and to active participation in decision-making processes by citizens.

These legal reference frameworks should have three main objectives:

- $\quad$ preserve the variety of the natural world by protecting geodiversity and biodiversity of ecosystems as a form of respect for the natural evolutionary trajectory;

- guarantee to human societies the richness and quality of ecosystem services for the legitimate sustenance of civilizations, paying particular attention to indigenous groups, which can often be considered exemplary ethical communities in managing a relationship of respect and balance with ecosystem dynamics [41];

- create a knowledge society that aims to provide citizens with information, data, and tools to better frame issues of general interest from a scientific and humanities point of view, including those that refer to global warming, climate change, and related geopolitical social problems, initiating in citizenship that growth of awareness capable of forming responsible citizens from a social and environmental point of view, citizens able to face the great global challenges both by choosing ruling classes that are up to their tasks, and by engaging directly in their daily life, based on their possibilities, abilities, and skills.

\section{Conclusions}

This is the time to take action to abandon the irresponsible positions of those who call for the extinction of humanity to preserve the naturalness of the planet, as well as those who live in the apathy of the status quo, favouring an existential dissociation that nurtures the dichotomy between the human being and nature.

We believe that the ecological crisis is triggered by a crisis of the human being. This crisis is not attributable to the anthropocentric vision of the human being, which we consider inevitable, but rather to its lack of responsibility towards the choices that affect its interaction with nature. Minimising human agents' responsibility is due to deficiencies in the pedagogical objectives of the educational systems and the mis-directing of citizens by political and economic powers that are interested only in the economic exploitation of nature.

Therefore, if the anthropocentric positions have always been considered the cause of that attitude of part of humanity, especially of the richest societies, which would have triggered the ecological crisis, the proposal to embrace more ecologically-oriented positions, such as those of biocentrism and ecocentrism (or geocentrism as its planetary extension), has been suggested to solve environmental problems.

In our vision, there is no biocentrism, ecocentrism, or geocentrism that does not imply a responsible anthropocentrism at the basis of a relationship of respect for the human being with other non-human entities. Geoethics seeks a position of synthesis between these different visions, recalling in any case the adoption of a form of anthropocentrism illuminated by the principle of responsibility. 
From the perspective of geoethics, humanity must take responsibility for the damage caused by its historical domination over nature, to change course and renew itself in the deepest dimension of its relationship with the planet, trying to achieve a more responsible and ecologically oriented way of life, in the light of scientific and humanities knowledge and modern technological advances.

Our proposal is to adopt the vision, principles, and values of geoethics to shape a new imagery of society, new forms of communication, new ways to build relationships, new tools to educate people to be respectful and inclusive, new structures of societal organization, and new approaches to the natural environment. Law- and decision-makers would benefit to build codes and policies by referring to the ethical framework proposed by geoethics for guaranteeing equity, inclusivity, environmental stewardship and protection, safety, health, and sustainability. Additionally, industry and commercial undertakings would increase their societal credibility and environmental liability by introducing geoethics into their practices.

This is the goal of geoethics, a project for the individual that becomes a project for more sustainable societies, intended as human structures capable of assuring to citizens human rights, equal opportunities, inclusivity in defining societal needs and priorities, democratic political processes in law- and decision-making, renewable production of energy, low impact agricultural systems, low water consumption, ethical farming practices, protection of ecosystems, conservation of biodiversity, minimization of anthropic impact on geodiversity, healthy and safe conditions for human life while assuring adequate living spaces to other biological entities, and pollution and greenhouse gas emissions reduction. Geoethics can be developed as a global ethics to create conditions for a responsible human development, which includes economic development intended as a transition to a substantially circular economy with a reduced ecological impact. Responsible human development is a broader and better focused concept than simple sustainable development (that is more closely linked to economic needs), as it assigns humanity the task and responsibility of making society sustainable, so that it is more just, fair, supportive, inclusive, educated, participatory, and ecologically oriented. Achieving more responsible human development means increasing the overall awareness and social, economic, cultural, and ecological responsibility of human agents, according to the possibilities of each person, in order to pursue a true progress of civilization.

Author Contributions: Writing—original draft, S.P. and G.D.C. Both authors have read and agreed to the published version of the manuscript.

Funding: This research received no external funding.

Acknowledgments: We thank David C. Ovadia for his comments and suggestions, and for reviewing the English.

Conflicts of Interest: The authors declare no conflict of interest.

\section{References}

1. Di Capua, G.; Peppoloni, S. Defining Geoethics. Website of the IAPG-International Association for Promoting Geoethics. 2019. Available online: http:/ / www.geoethics.org/definition (accessed on 5 July 2021).

2. Peppoloni, S.; Bilham, N.; Di Capua, G. Contemporary Geoethics Within the Geosciences. In Exploring Geoethics-Ethical Implications, Societal Contexts, and Professional Obligations of the Geosciences; Bohle, M., Ed.; Palgrave Pivot: Cham, Switzerland, 2019; pp. 25-70. [CrossRef]

3. Berkes, F.; Folke, C. Linking Social and Ecological Systems; Cambridge University Press: Cambridge, UK, 1998; ISBN 978-0521785624.

4. Ostrom, E. A general framework for analyzing sustainability of social-ecological systems. Science 2009, 325, 419-422. [CrossRef] [PubMed]

5. Preiser, R.; Biggs, R.; De Vos, A.; Folke, C. Social-ecological systems as complex adaptive systems: Organizing principles for advancing research methods and approaches. Ecol. Soc. 2018, 23, 46. [CrossRef]

6. De Vos, A.; Biggs, R.; Preiser, R. Methods for understanding social-ecological systems: A review of place-based studies. Ecol. Soc. 2019, 24, 16. [CrossRef]

7. Wyss, M.; Peppoloni, S. Geoethics: Ethical Challenges and Case Studies in Earth Sciences; Elsevier: Amsterdam, The Netherlands, 2015; 450p, ISBN 978-0127999357. [CrossRef] 
8. Peppoloni, S.; Di Capua, G.; Bobrowsky, P.T.; Cronin, V.S. Geoethics at the Heart of all Geoscience. Ann. Geophys. $2017,60$. Available online: https://www.annalsofgeophysics.eu/index.php/annals/issue/view/537 (accessed on 5 July 2021).

9. Bohle, M. Exploring Geoethics: Ethical Implications, Societal Contexts, and Professional Obligations of the Geosciences; Palgrave Pivot: Cham, Switzerland, 2019; p. XIV + 214. ISBN 978-3030120092. [CrossRef]

10. Peppoloni, S. Geoscienze, geoetica e diritto (in English: Geosciences, geoethics, and law). In Il Diritto Visto da Fuori: Scienziati, Intellettuali, Artisti si Interrogano sul Senso della Giuridicità Oggi; Zanichelli, M., Ed.; FrancoAngeli: Milano, Italy, 2020; 210p, ISBN 978-8835106845.

11. Vasconcelos, C.; Schneider-Voß, S.; Peppoloni, S. Teaching Geoethics: Resources for Higher Education; U.Porto Edições: Porto, Portugal, 2020; 207p, ISBN 978-9897462542. [CrossRef]

12. Abrunhosa, M.; Chambel, A.; Peppoloni, S.; Chaminé, H.I. Advances in Geoethics and Groundwater Management: Theory and practice for a sustainable development. In Proceedings of the 1st Congress on Geoethics and Groundwater Management (GEOETHEGWM'20), Porto, Portugal, 18-22 May 2020; Springer: Berlin/Heidelberg, Germany, 2021; p. XLV + 523. ISBN 978-3030-59319-3. [CrossRef]

13. Di Capua, G.; Bobrowsky, P.T.; Kieffer, S.W.; Palinkas, C. Geoethics: Status and Future Perspectives; Special Publications; Geological Society: London, UK, 2021; pp. 508, VIII+311, ISBN 978-1786205384. [CrossRef]

14. Bohle, M.; Marone, E. Geoethics, a Branding for Sustainable Practices. Sustainability 2021, 13, 895. [CrossRef]

15. Bohle, M.; Marone, E. (Eds.) Geo-Societal Narratives: Contextualising Geosciences; Palgrave Macmillan: London, UK, 2021; p. IV + 260, ISBN 978-3030790271. [CrossRef]

16. Peppoloni, S.; Di Capua, G. Geoethics as global ethics to face grand challenges for humanity. In Geoethics: Status and Future Perspectives; Di Capua, G., Bobrowsky, P.T., Kieffer, S.W., Palinks, C., Eds.; Geological Society: London, UK, 2021 ; pp. 13-29. [CrossRef]

17. Mogk, D.W.; Bruckner, M.Z. Geoethics training in the Earth and environmental sciences. Nat. Rev. Earth Environ. 2020, 1, 81-83. [CrossRef]

18. Peppoloni, S.; Di Capua, G. Current Definition and Vision of Geoethics. In Geo-Societal Narratives: Contextualising Geosciences; Bohle, M., Marone, E., Eds.; Palgrave Macmillan: London, UK, 2021. [CrossRef]

19. Reclus, E. L'Homme et la Terre (1905-1908); Librairie Universelle: Paris, France, 1905.

20. Peppoloni, S.; Di Capua, G. Geoetica: Manifesto per Un'Etica della Responsabilità verso la Terra; Donzelli Editore: Roma, Italy, 2021; p. 224, ISBN 978-8855221696.

21. Morin, E. Changeons de Voie: Les Leçons du Coronavirus; Éditions Denoël: Paris, France, 2020.

22. Ripple, W.J.; Wolf, C.; Newsome, T.M.; Barnard, P.; Moomaw, W.R.; 11,258 Scientist Signatories from 153 Countries. World Scientists' Warning of a Climate Emergency. BioScience 2020, 70, 8-12. [CrossRef]

23. Jouffray, J.-B.; Blasiak, R.; Norström, A.V.; Österblom, H.; Nyström, M. The Blue Acceleration: The Trajectory of Human Expansion into the Ocean. Perspective 2020, 2, 43-54. [CrossRef]

24. IPBES-IPCC. Biodiversity and Climate Change. 2021. Available online: https://ipbes.net/sites/default/files/2021-06/2021 _IPCC-IPBES_scientific_outcome_20210612.pdf (accessed on 5 July 2021).

25. Peppoloni, S.; Di Capua, G. The Meaning of Geoethics. In Geoethics: Ethical Challenges and Case Studies in Earth Sciences; Wyss, M., Peppoloni, S., Eds.; Elsevier: Amsterdam, The Netherlands, 2015; pp. 3-14. [CrossRef]

26. Bobrowsky, P.; Cronin, V.; Di Capua, G.; Kieffer, S.W.; Peppoloni, S. The Emerging Field of Geoethics. In Scientific Integrity and Ethics: With Applications to the Geosciences; AGU Special Publication; Gundersen, L.C., Ed.; Wiley: Hoboken, NJ, USA, 2017; pp. 175-212. [CrossRef]

27. Bohle, M. Geo-societal sense-making. In Geoethics: Status and Future Perspectives; Di Capua, G., Bobrowsky, P.T., Kieffer, S.W., Palinks, C., Eds.; The Geological Society: London, UK, 2021; pp. 31-46. [CrossRef]

28. Stewart, I.S.; Lewis, D. Communicating contested geoscience to the public: Moving from 'matters of fact' to 'matters of concern'. Earth-Sci. Rev. 2017, 174, 122-133. [CrossRef]

29. Peppoloni, S.; Di Capua, G. Geoethics: Ethical, Social, and Cultural Values in Geosciences Research, Practice, and Education. In Geoscience for the Public Good and Global Development: Toward a Sustainable Future; Special Papers; Wessel, G.R., Greenberg, J.K., Eds.; Geological Society of America: Boulder, CO, USA, 2016; pp. 17-21. [CrossRef]

30. Di Capua, G.; Peppoloni, S.; Bobrowsky, P.T. The Cape Town Statement on Geoethics. Ann. Geophys. 2017, 60. [CrossRef]

31. Gray, M. Geodiversity: The Backbone of Geoheritage and Geoconservation. In Geoheritage: Assessment, Protection, and Management; Reynard, E., Brilha, J., Eds.; Elsevier: Amsterdam, The Netherlands, 2018; pp. 13-25. [CrossRef]

32. Reynard, E.; Giusti, C. The Landscape and the Cultural Value of Geoheritage. In Geoheritage: Assessment, Protection, and Management; Reynard, E., Brilha, J., Eds.; Elsevier: Amsterdam, The Netherlands, 2018; pp. 147-166. [CrossRef]

33. Jonas, H. Das Prinzip Verantwortung: Versuch einer Ethik für die technologische Zivilisation [The Imperative of Responsibility: Search of Ethics for the Technological Age]; Suhrkamp; Jonas, F.H.; Herr, D., Translators; University of Chicago Press: Chicago, IL, USA, 1984; ISBN 0-226405974.

34. Peppoloni, S.; Di Capua, G. Geoethics and Geological Culture: Awareness, Responsibility and Challenges. Ann. Geophys. 2012, 55, 335-341. [CrossRef] 
35. Conceição, P.; Assa, J.; Calderon, C.; Pavez Esbry, F.; Fuentes, R.; Hsu, Y.-C.; Kovacevic, M.; Lengfelder, C.; Lutz, B.; Mirza, T.; et al. The Next Frontier: Human development and the Anthropocene; Human Development Report 2020; United Nations Development Programme: New York, NY, USA, 2020; ISBN 978-9211264425.

36. Kashwan, P.; Biermann, F.; Gupta, A.; Okereke, C. Planetary justice: Prioritizing the poor in earth system governance. Earth Syst. Gov. 2020, 6, 100075. [CrossRef]

37. UN-DESA. Inequality in a Rapidly Changing World; World Social Report 2020, ST/ESA/372; United Nations-Department of Economic and Social Affairs: New York, NY, USA, 2020; ISBN 978-9211303926.

38. Stiglitz, J.E. Globalization and Inequality: Coping with the Consequences; Princeton University: Princeton, NJ, USA, 2016. Available online: https://www8.gsb.columbia.edu/faculty/jstiglitz/sites/jstiglitz/files/Inequality\%20Presentation.pdf (accessed on 5 July 2021).

39. Heimberger, P. Does economic globalisation affect income inequality? A meta-analysis. World Econ. 2020, 43, 2960-2982. [CrossRef]

40. Heinze, J. The Impact of Globalisation on Poverty and Inequality in the Global South. E-International Relations. 2020. Available online: https: / www.e-ir.info/2020/03/22/the-impact-of-globalisation-on-poverty-and-inequality-in-the-global-south/ (accessed on 5 July 2021).

41. Conversi, D. Exemplary Ethical Communities. A New Concept for a Livable Anthropocene. Sustainability 2021, $13,5582$. [CrossRef]

42. Blühdorn, I.; Welsh, I. Eco-politics beyond the paradigm of sustainability: A conceptual framework and research agenda. Environ. Politics 2007, 16, 185-205. [CrossRef]

43. Clark, N.; Gunaratnam, Y. Earthing the Anthropos? From 'Socialising the Anthropocene' to Geologising the Social. In Delanty, G. (ed.), Agency and Historical Time: Social Theory in the Age of the Anthropocene, 20th Anniversary Special Issue. Eur. J. Soc. Theory 2017, 20, 146-163. [CrossRef]

44. Stubblefield, C. Managing the Planet: The Anthropocene, Good Stewardship, and the Empty Promise of a Solution to Ecological Crisis. Societies 2018, 8, 38. [CrossRef]

45. Lövbrand, E.; Mobjörkb, M.; Söder, R. The Anthropocene and the geo-political imagination: Re-writing Earth as political space. Earth Syst. Gov. 2020, 4, 100051. [CrossRef]

46. Marques, L. Capitalism and Environmental Collapse; Springer: Cham, Switzerland, 2020; p. XX + 459, ISBN 978-3-030-47526-0. [CrossRef]

47. Bonneuil, C.; Fressoz, J.-B. L'événement Anthropocène-La Terre, L'histoire et Nous; Le Seuil: Paris, France, 2013; 320p, ISBN 9782021135008.

48. Lewis, S.L.; Maslin, M.A. The Human Planet: How We Created the Anthropocene; Pelican: London, UK, 2018; 480p, ISBN 9780241280881

49. Rockström, J.; Steffen, W.; Noone, K.; Persson, Å.; Chapin, F.S., III; Lambin, E.F.; Lenton, T.M.; Scheffer, M.; Folke, C.; Schellnhuber, H.J.; et al. A safe operating space for humanity. Nature 2009, 461, 472-475. [CrossRef]

50. Steffen, W.; Richardson, K.; Rockström, J.; Cornell, S.E.; Fetzer, I.; Bennett, E.M.; Biggs, R.; Carpenter, S.R.; de Vries, W.; de Wit, C.A.; et al. Planetary boundaries: Guiding human development on a changing planet. Science 2015, 347, 1259855. [CrossRef]

51. Steffen, W.; Rockström, J.; Richardson, K.; Lenton, T.M.; Folke, C.; Liverman, D.; Summerhayes, C.P.; Barnosky, A.D.; Cornell, S.E.; Crucifix, M.; et al. Trajectories of the Earth system in the anthropocene. Proc. Natl. Acad. Sci. USA 2018, 115, 8252-8259. [CrossRef]

52. Xu, C.; Kohler, T.A.; Lenton, T.M.; Svenning, J.-C.; Scheffer, M. Future of the human climate niche. Proc. Natl. Acad. Sci. USA 2020, 117, 11350. [CrossRef] [PubMed]

53. Folke, C.; Polasky, S.; Rockström, J.; Galaz, V.; Westley, F.; Lamont, M.; Scheffer, M.; Österblom, H.; Carpenter, S.R.; Chapin, I.I.I.F.S.; et al. Our future in the Anthropocene biosphere. Ambio 2021, 50, 834-869. [CrossRef] [PubMed]

54. Burke, A.; Fishel, S.; Mitchell, A.; Dalby, S.; Levine, D.J. Planet politics: A manifesto from the end of IR. Millennium 2016, 44, 499-523. [CrossRef]

55. Xu, Y.; Ramanathan, V. Well below $2{ }^{\circ} \mathrm{C}$ : Mitigation strategies for avoiding dangerous to catastrophic climate changes. Proc. Natl. Acad. Sci. USA 2017, 114, 10315-10323. [CrossRef]

56. Boivin, N.; Crowther, A. Mobilizing the past to shape a better Anthropocene. Nat. Ecol. Evol. 2021, 5, 273-284. [CrossRef]

57. Rockström, J.; Gupta, J.; Lenton, T.M.; Qin, D.; Lade, S.J.; Abrams, J.F.; Jacobson, L.; Rocha, J.C.; Zimm, C.; Bai, X.; et al. Identifying a safe and just corridor for people and the planet. Earth's Future 2021, 9, e2020EF001866. [CrossRef]

58. Göpel, M. Introduction. In The Great Mindshift: How a New Economic Paradigm and Sustainability Transformations go Hand in Hand. The Anthropocene: Politik-Economics-Society-Science; Göpel, M., Ed.; Springer: Cham, Switzerland, 2016; Volume 2, pp. 1-11. [CrossRef]

59. Mazzucato, M. Mission Economy: A Moonshot Guide to Changing Capitalism; Allen Lane: London, UK, 2021; 272p, ISBN 9780241419731.

60. Löwy, M. Ecosocialism: A Radical Alternative. In Reflections on Socialism in the Twenty-First Century; Brundenius, C., Ed.; Springer: Cham, Switzerland, 2020; pp. 199-210, ISBN 978-3030339197. [CrossRef]

61. UN. The Universal Declaration of Human Rights; United Nations: New York, NY, USA, 1948. Available online: https://www.un. org/en/about-us/universal-declaration-of-human-rights (accessed on 5 July 2021). 
62. Kopnina, H.; Washington, H.; Taylor, B.; Piccolo, J.J. Anthropocentrism: More than Just a Misunderstood Problem. J. Agric. Environ. Ethics 2018, 31, 109-127. [CrossRef]

63. Peppoloni, S.; Di Capua, G. Geoethics: Ethical, Social and Cultural Implications in Geosciences. Ann. Geophys. 2017, 60. [CrossRef]

64. Taylor, P.W. The Ethics of Respect for Nature. Environ. Ethics 1981, 3, 197-218. [CrossRef]

65. Taylor, P.W. In Defense of Biocentrism. Environ. Ethics 1983, 5, 237-243. [CrossRef]

66. Leopold, A. A Sand County Almanac: And Sketches Here and There; Oxford University Press: New York, NY, USA, 1949.

67. Naess, A. The shallow and the deep, long-range ecology movement. A summary. Inquiry 1973, 16, 95-100. [CrossRef]

68. Callicott, J.B. The Conceptual Foundations of the Land Ethic. In Companion to a Sand County Almanac: Interpretive and Critical Essays; Callicott, J.B., Ed.; University of Wisconsin Press: Madison, WI, USA, 1987; pp. 186-217, ISBN 0-299-11230-6.

69. McShane, K. Ecocentrism. In Critical Environmental Politics; Death, C., Ed.; Routledge: London, UK, 2014; pp. 83-90, ISBN 9781315883076.

70. Rolston, H. Challenges in Environmental Ethics. In Environmental Philosophy: From Animal Rights to Radical Ecology, 2nd ed.; Zimmerman, M.E., Callicott, J.B., Sessions, G., Warren, K.J., Clark, J., Eds.; Prentice Hall: Upper Saddle River, NJ, USA, 1998; pp. 124-144.

71. Hourdequin, M. Environmental Ethics: From Theory to Practice; Bloomsbury Academic: London, UK, 2015; 256p, ISBN 9781472508089.

72. Norton, B.G. Environmental ethics and weak anthropocentrism. Environ. Ethics 1984, 6, 131-148. [CrossRef]

73. Viola, F. Stato e Natura; Edizioni Anabasi SPA: Milano, Italy, 1995; ISBN 88-41780169.

74. Passmore, J.A. Man's Responsibility for Nature: Ecological Problems and Western Traditions; Duckworth: London, UK, 1974; 213p, ISBN 978-0715608197.

75. Capra, F. The Tao of Physics: An Exploration of the Parallels Between Modern Physics and Eastern Mysticism; Shambhala: Boulder, CO, USA, 1975; ISBN O-87773-077-6.

76. Morris, T. Hans Jonas's Ethic of Responsibility: From Ontology to Ecology; State University of New York Press: New York, NY, USA, 2013; ISBN 978-1438448817.

77. Ellis, E.C.; Gauthier, N.; Goldewijk, K.K.; Bird, R.B.; Boivin, N.; Díazi, S.; Fuller, D.Q.; Gill, J.L.; Kaplanm, J.O.; Kingston, N.; et al. People have shaped most of terrestrial nature for at least 12,000 years. Proc. Natl. Acad. Sci. USA 2021, 118, e2023483118. [CrossRef]

78. Dubos, R. A God Within; Scribner's: New York, NY, USA, 1972.

79. Thomas, M.; Buckmaster, L. Paternalism in Social Policy When Is It Justifiable? Research Paper No. 8 2010-11. 2010. Available online: https:/ / www.aph.gov.au/About_Parliament/Parliamentary_Departments/Parliamentary_Library/pubs/rp/rp1011/ 11rp08\#_Toc280187797 (accessed on 5 July 2021).

80. Grill, K. Paternalism. In Encyclopedia of Applied Ethics, 2nd ed.; Chadwick, R., Ed.; Elsevier: San Diego, CA, USA, 2012; pp. 359-369. [CrossRef] 